\title{
UPAYA HUKUM DALAM PENYELESAIAN SENGKETA PERDAGANGAN EMAS BERJANGKA PADA PT. RIFAN FINANCINDO BERJANGKA PEKANBARU*
}

\author{
Aswandi \\ Fakultas Hukum, Universitas Andalas Padang \\ e-mail: andimaestro54a@yahoo.com
}

\begin{abstract}
Gold futures trading is very vulnerable to disputes. Therefore, understanding the efforts to resolve futures trade disputes is very important to know. This research was conducted empirically, the nature of descriptive analysis research with qualitative data analysis. Futures trading dispute at PT. Rifan Financindo Berjangka Pekanbaru is caused by customer misunderstanding about the process and legal aspects of futures trading. This was made worse by the lack of education conducted by futures brokers and the existence of unlawful acts committed by sales marketing and futures broker representatives. Gold futures trade dispute settlement can only be done by litigation in the South Jakarta District Court or non-litigation through the Commodity Futures Trading Arbitration Board. Constraints encountered in resolving disputes are; disproportionate choice of dispute resolution forums, lack of customer understanding of legal aspects in resolving disputes and violations of Standard Dispute Resolution Operational Procedures.
\end{abstract}

Keywords: Gold futures; Dispute resolution; Litigation; Non-litigation.

\begin{abstract}
Abstrak
Perdagangan emas berjangka sangat rawan dengan sengketa. Karena itu, pemahaman terhadap upaya penyelesaian sengketa perdagangan berjangka sangat penting untuk diketahui. Penelitian ini dilakukan secara yuridis empiris, sifat penelitian deskriptif analisis dengan analisa data secara kualitatif. Sengketa perdagangan berjangka pada PT. Rifan Financindo Berjangka Pekanbaru disebabkan karena ketidakpahaman nasabah tentang proses dan aspek hukum perdagangan berjangka. Hal itu diperparah lagi dengan tidak maksimalnya edukasi yang dilakukan pialang berjangka serta adanya tindakan melanggar hukum yang dilakukan sales marketing dan wakil pialang berjangka. Penyelesaian sengketa perdagangan emas berjangka hanya dapat dilakukan secara litigasi di Pengadilan Negeri Jakarta Selatan atau secara non-litigasi melalui Badan Arbitrase Perdagangan Berjangka Komoditi. Kendala yang ditemui dalam penyelesaian sengketa, adalah; pilihan forum penyelesaian sengketa yang tidak proporsional, kurangnya pemahaman nasabah terhadap aspek hukum dalam penyelesaian sengketa dan pelanggaran Prosedur Operasional Standar penyelesaian sengketa.
\end{abstract}

Kata Kunci: Emas berjangka; Penyelesaian Sengketa; Litigasi; Non-litigasi.

\footnotetext{
* Naskah diterima: 16 November 2018, direvisi: 21 Maret 2019, disetujui untuk terbit: 26 Maret 2019 Doi: $\underline{10.3376 / \text { jch.v4i2.107 }}$
} 


\section{PENDAHULUAN}

Proses jual beli komoditi dengan penarikan margin dan dengan penyelesaian kemudian berdasarkan kontrak berjangka, kontrak derivatif syariah, dan/atau kontrak derivatif lainnya dinamakan dengan perdagangan berjangka. Berbeda dengan perdagangan pada umumnya yang dilakukan dengan adanya pertemuan antara para pelaku pasar, perdagangan berjangka tidak mengenal adanya pertemuan antara penjual dengan pembeli secara langsung, bahkan serah terima barang yang diperjualbelikan pun tidak pernah dilakukan. Hal ini dikarenakan fungsi ekonomi dari perdagangan berjangka bukanlah jual beli barang, melainkan sarana lindung nilai (hedging) serta sarana penciptaan harga. Perdagangan emas berjangka merupakan salah satu bentuk dari perdagangan berjangka komoditi.

Sebagai sebuah perdagangan yang memiliki sifat high risk high return, sudah selayaknya perdagangan emas berjangka ini memiliki payung hukum yang jelas dan mampu memberikan kepastian bagi setiap pelaku pasar. Untuk mengakomodir kebutuhan pelaku pasar tersebut, pemerintah telah mengeluarkan UndangUndang dan peraturan pelaksana tentang perdagangan berjangka. Sampai saat ini, masih terdapat dualisme dalam pengurusan perizinan dan otoritas dalam pengaturan dan pengawasan perdagangan berjangka. Otoritas tersebut berada pada Badan Pengawas Perdagangan Berjangka Komoditi (Bappebti) dan Otoritas Jasa Keuangan (OJK). Bagi perusahaan perdagangan berjangka yang perizinannya dikeluarkan oleh Bappebti, maka perusahaan tersebut berada dalam pengawasan dan tunduk pada aturan Bappebti, yang secara hirarki berada di bawah kementerian perdagangan. Bagi perusahaan perdagangan berjangka yang perizinannya dikeluarkan oleh Otoritas Jasa Keuangan maka pengaturan dan pengawasannya tunduk pada aturan OJK yang secara hirarki berada di bawah kementerian keuangan.

PT. Rifan Financindo Berjangka Pekanbaru merupakan sebuah perusahaan pialang berjangka yang berada di bawah naungan Kementerian Perdagangan bersama dengan enam puluh enam perusahaan pialang berjangka lainnya di Indonesia. Karena itu, PT. Rifan Financindo berada di bawah pengawasan Bappebti dan diatur menurut aturan yang dikeluarkan oleh kementerian perdagangan dan badan-badan yang berada di bawahnya.

Undang-Undang Nomor 32 Tahun 1997 sebagaimana yang telah dirubah dengan Undang-Undang Nomor 10 Tahun 2011 tentang Perdagangan Berjangka Komoditi merupakan payung hukum utama bagi nasabah dan perusahaan pialang berjangka yang berada di bawah naungan Bappebti. Dalam bagian menimbang undang-undang tersebut dinyatakan: "Dalam upaya untuk lebih menjamin kepastian hukum, keadilan, transparansi dan akuntabilitas pelayanan publik, untuk mendukung upaya peningkatan dan pengembangan perekonomian nasional yang berkaitan dengan perdagangan global, serta agar 
Aswandi: Upaya Hukum Dalam Penyelesaian Sengketa Perdagangan Emas Berjangka...

perdagangan berjangka komoditi yang bertujuan meningkatkan usaha komoditi dapat terselenggara secara teratur, wajar, efesien, efektif dan terlindunginya masyarakat dari tindakan yang merugikan serta memberikan kepastian hukum kepada semua pihak yang melakukan kegiatan perdagangan berjangka komoditi, perlu pengaturan yang lebih jelas dalam pelaksanaan perdagangan berjangka komoditi”.

Dalam kenyataannya, meskipun pemerintah telah mengeluarkan undangundang dan beberapa peraturan pelaksana terkait dengan perdagangan berjangka, masih banyak nasabah yang merasa dirugikan oleh perbuatan tidak bertanggung jawab perusahaan pialang berjangka. Banyak nasabah yang merasa tertipu oleh sales marketing perusahaan pialang berjangka sehingga menderita kerugian sampai ratusan juta bahkan miliaran Rupiah. Seorang nasabah dengan inisial "Y" mengalami kerugian sebesar Rp. 350.000.000,- (tiga ratus lima puluh juta rupiah) dalam kurun waktu tiga bulan. Nasabah tersebut diajak untuk berinvestasi pada PT. Rifan Pekanbaru dengan jaminan keuntungan sebesar Rp. 1.000.000,- (satu juta rupiah) untuk setiap harinya. Rekening dan kode password nasabah tersebut dipegang oleh sales marketing perusahaan. Seluruh transaksi juga dilakukan oleh pihak perusahaan, nasabah tersebut tidak pernah melakukan transaksi.

Pada awalnya, nasabah menyetorkan uang sebanyak Rp. 100.000.000,- (seratus juta rupiah). Tidak lebih dari satu bulan, setoran pertama tersebut habis karena transaksi yang dilakukan oleh pihak perusahaan. Untuk menyelamatkan akun nasabah tersebut, pihak perusahaan meminta nasabah untuk melakukan penambahan margin dengan menyetorkan kembali sejumlah uang. Waktu itu nasabah melakukan penambahan margin sebesar Rp. 250.000.000,- (dua ratus lima puluh juta rupiah). Tidak lebih dari dua bulan, seluruh uang yang disetorkan nasabah pada setoran kedua tersebut juga habis dalam transaksi yang dilakukan oleh pihak perusahaan.

Ketika nasabah menuntut haknya, seperti yang telah dijanjikan oleh sales marketing, pihak perusahaan balik menyalahkan nasabah karena tidak bisa menjaga akun dan kode passwordnya sendiri. Pihak perusahaan lepas tangan dan tidak mau bertanggung jawab terhadap kerugian nasabah tersebut. Jika berpedoman kepada Undang-Undang Nomor 10 tahun 2011 tentang Perdagangan Berjangka, perbuatan sales marketing perusahaan yang memberikan garansi keuntungan dan memegang serta memainkan akun nasabah tersebut adalah perbuatan yang tidak dibenarkan.

Keadaan tersebut di atas tentunya dapat menimbulkan konflik antara nasabah dengan PT. Rifan Financindo Berjangka Pekanbaru. Tidak jarang konflik tersebut berkembang menjadi sengketa perdagangan berjangka. Sayangnya tidak semua nasabah mengerti dengan aspek hukum penyelesaian sengketa perdagangan berjangka. Hal tersebut menyebabkan tidak maksimalnya upaya dalam penyelesaian sengketa. Nasabah 
dihadapkan kepada permasalahan yang mereka sendiri tidak siap dan tidak mempunyai pengetahuan yang cukup tentang permasalahan yang sedang dihadapi. Keadaan tersebut di atas, penulis jadikan sebagai sebuah indikasi akan adanya sesuatu yang layak untuk diteliti pada PT. Rifan Financindo Berjangka Pekanbaru.

Pokok permasalahan dalam penelitian ini adalah: Pertama, apa faktor penyebab terjadinya sengketa perdagangan emas berjangka pada PT. Rifan Financindo Berjangka Pekanbaru? Kedua, apa upaya hukum dalam penyelesaian sengketa perdagangan emas berjangka pada PT. Rifan Financindo Berjangka Pekanbaru? Ketiga, apa saja kendala-kendala yang ditemukan dalam penyelesaian sengketa perdagangan emas berjangka pada PT. Rifan Financindo Berjangka Pekanbaru?

\section{METODE PENELITIAN}

Metode penelitian yang digunakan dalam ini adalah metode yuridis empiris. Penelitian yuridis empiris adalah penelitian hukum yang menganalisa dan mengkaji bekerjanya hukum dalam masyarakat. Bekerjanya hukum dalam masyarakat dapat dikaji dari tingkat efektifitasnya hukum, kepatuhan terhadap hukum, peranan lembaga penegak hukum dan implementasi aturan hukum (Salim H.S. dan Erlies Septiana Nurbani, 2016: 20). Sifat dari penelitian ini adalah deskriptif analisis, yaitu penelitian yang dilakukan dengan cara menganalisa setiap pokok permasalahan dengan tujuan untuk memberikan gambaran secara jelas dan menyeluruh tentang objek yang diteliti.
Jenis data dalam penelitian ini adalah data primer dan data sekunder. Data primer merupakan data yang diperoleh langsung dari lapangan, yaitu dari pihakpihak yang secara langsung terlibat dengan permasalahan yang diteliti. Data sekunder merupakan data yang diperlukan sebagai pendukung data primer. Data sekunder dalam penelitian ini dapat berbentuk kontrak perdagangan berjangka dan kesepakatan-kesepakatan antara pihak yang bersengketa (Salim H.S. dan Erlies Septiana Nurbani, 2016: 25).

\section{HASIL DAN PEMBAHASAN}

Agus Yudha Hernoko mengungkapkan bahwa sengketa bisnis dalam kontrak komersial seringkali berawal dari faktor-faktor mendasar yang sudah ada sebelum pelaksanaan kontrak. Faktor-faktor atau penyebabnya, terjadinya sengketa tersebut antara lain:

1. Ketidakpahaman terhadap proses bisnis yang dilakukan. Kondisi ini muncul ketika pelaku bisnis sematamata terjebak pada orientasi keuntungan serta karakter coba-coba (gambling) tanpa memprediksi kemungkinan risiko yang akan menimpanya.

2. Ketidakmampuan mengenali partner atau mitra bisnisnya. Ada pelaku bisnis yang sekedar memperhatikan performa atau penampilan fisik mitra bisnisnya tanpa meneliti lebih lanjut track record dan bonafiditas.

3) Tidak adanya legal cover yang melandasi proses bisnis dan apresiasi hukum pelaku bisnis dalam 
Aswandi: Upaya Hukum Dalam Penyelesaian Sengketa Perdagangan Emas Berjangka...

melindungi aktifitas bisnis mereka (Agus Yudha Hernoko, 2014: 305).

Jika kita cermati pendapat ahli tersebut di atas dan dikaitkan dengan praktek perdagangan emas berjangka pada PT. Rifan Financindo Berjangka Pekanbaru, akan didapat beberapa faktor penyebab timbulnya sengketa perdagangan emas berjangka. Faktor-faktor penyebab tersebut adalah :

Pertama, ketidakpahaman nasabah terhadap tata cara perdagangan emas berjangka. Sebagai sebuah bisnis yang memiliki potensi keuntungan yang besar yang dibarengi dengan tingkat risiko yang tinggi (high risk high return), seharusnya sebelum masuk pasar, pelaku bisnis memiliki pemahaman yang benar tentang perdagangan berjangka komoditi. Dalam perdagangan berjangka komoditi, khususnya kontrak emas berjangka, fluktuasi harga terjadi dengan begitu cepatnya. Perubahan harga dapat terjadi dalam hitungan jam, menit, bahkan dalam hitungan detik. Karena itu, kemampuan untuk membaca atau menganalisa pergerakan pasar harus dimiliki oleh nasabah.

Ada dua bentuk analisa pasar yang lazim digunakan dalam Kontrak Gulir Emas Harian Loco London, yaitu analisa teknikal dan analisa fundamental. Metode dasar untuk membaca pergerakan harga dengan menggunakan data historis berupa kombinasi nilai harga pembukaan, penutupan, harga tertinggi dan harga terendah dinamakan analisa teknikal. Analisa teknikal selalu menggunakan grafik-grafik yang berfungsi sebagai dasar utama untuk membaca pergerakan harga dan sangat baik untuk mengevaluasi harga dalam rentang waktu yang pendek (Ellen May, 2011: 38).

Informasi mengenai laporan keuangan dan kesehatan perusahaan, manajemen perusahaan, pesaing dan situasi pasar dari produk tersebut merupakan instrument yang dapat digunakan dalam melakukan analisa fundamental. Kedua alat analisa ini bisa digunakan secara bersamaan, namun bisa juga digunakan hanya salah satu dari keduanya tergantung kecenderungan pelaku pasar (trader). Apabila trader cenderung untuk fokus pada pergerakan harga sebaiknya menggunakan analisa teknikal. Apabila trader lebih memilih untuk mencari informasi mengenai perusahaan terkait dan isu ekonomi global maka alat analisa yang digunakan adalah analisa fundamental (Ellen May, 2011: 34)

Hal lain yang harus dikuasai traders sebelum melakukan perdagangan berjangka komoditi adalah pengetahuan tentang manajemen risiko. Ada empat trend yang bisa terjadi dalam dunia forex trading, yakni trend naik (bullish), trend turun (bearish), trend mendatar (sideway) dan trend acak (chaos). Trend chaos merupakan trend yang umumnya cukup dikhawatirkan oleh banyak traders. Trend chaos menunjukkan dinamika yang sangat sensitif terhadap kondisi awal. Pergerakan harga di pasar hanya dapat diperkirakan oleh seorang analis pasar, tidak satupun dari kedua metode analisa pasar dapat memberikan jawaban yang pasti tentang pergerakan harga. Untuk itu, traders juga dituntut untuk mengetahui trend yang 
terjadi di lapangan. Dengan mengetahui trend, traders bisa mengetahui strategi apa yang tepat untuk digunakan dalam mengambil posisi pasar dan apa yang harus dilakukan jika pergerakan pasar tidak seperti yang diharapkan.

Manajemen risiko merupakan salah satu cara yang digunakan untuk meminimalisasi kerugian. Manajemen risiko yang lazim digunakan dalam perdagangan berjangka komoditi, khususnya produk gold adalah: Cutloss, yaitu dengan cara menutup transaksi yang merugi sesegera mungkin dengan tujuan untuk menghindari risiko kerugian yang lebih besar. Switching, menutup posisi yang rugi dan segera mengambil posisi baru yang searah dengan pergerakan harga selanjutnya. Teknik ini lebih efektif apabila dilakukan ketika terjadi perubahan arah harga yang cepat dan drastis. Averaging, merupakan teknik manajemen risiko yang cukup ekstrim karena pada dasarnya teknik ini mencoba untuk "melawan" pasar. Ide dasarnya adalah pasar tidak mungkin bergerak ke satu arah saja untuk selamanya.

Untuk dapat melakukan manajemen risiko tersebut tentunya diperlukan pengetahuan tentang manajemen risiko. Sayangnya tidak semua nasabah memiliki pengetahuan tentang manajemen risiko tersebut. Menurut Agus Yudha Hernoko, kondisi seperti itu terjadi karena nasabah terjebak dengan orientasi keuntungan yang besar serta perilaku coba-coba (gambling) (Agus Yudha Hernoko, 2014: 305) Akibatnya, pada saat situasi pasar tidak terkontrol, nasabah menjadi panik sehingga melakukan hal-hal yang didasarkan kepada emosi dengan mengenyampingkan manajemen risiko.

Kedua, tidak maksimalnya upaya edukasi mengenai prosedur dan aspek hukum perdagangan berjangka yang dilakukan perusahaan pialang berjangka terhadap calon nasabah. Mengingat begitu tingginya tingkat risiko dalam perdagangan emas berjangka, nasabah dituntut untuk dapat memahami seluk beluk perdagangan berjangka. Untuk itu, pemerintah telah mengeluarkan regulasi terkait dengan keharusan akan adanya pemahaman dan kemampuan nasabah sebelum melakukan perdagangan berjangka komoditi. Ketentuan tersebut diatur di dalam Peraturan Kepala Badan Pengawas Perdagangan Berjangka Komoditi Nomor 64/BAPPEBTI/Per/1/ 2009 tentang Perubahan Atas Peraturan Kepala Badan Pengawas Perdagangan Berjangka Komoditi Nomor 63/BAPPEBTI/Per/9/2008 tentang Ketentuan Teknis Perilaku Pialang Berjangka.

Jika kita cermati pasal demi pasal yang terdapat pada peraturan kepala Bappebti tersebut, terlihat bahwa wakil pialang berjangka berkewajiban untuk memberikan edukasi kepada setiap calon nasabah perdagangan emas berjangka. Pasal 5 ayat (2) huruf c peraturan tersebut menyatakan: Dalam melaksanakan kegiatan perdagangan berjangka, pialang berjangka wajib membuat materi pelatihan mengenai perdagangan berjangka yang paling sedikit meliputi: 
Aswandi: Upaya Hukum Dalam Penyelesaian Sengketa Perdagangan Emas Berjangka...

1. Peraturan perundang-undangan di bidang perdagangan berjangka;

2. Pengetahuan tentang komoditi dan kontrak berjangka;

3. Pengetahuan tentang mekanisme transaksi dan risiko di bidang perdagangan berjangka;

4. Hak-hak dan kewajiban nasabah.

Untuk memaksimalkan upaya pemberian edukasi tersebut, peraturan telah memberikan batasan bahwa upaya edukasi hanya boleh dilakukan oleh wakil pialang berjangka. Jika wakil pialang berjangka berhalangan, maka pemberian edukasi tersebut hanya boleh digantikan oleh seseorang yang juga berkedudukan sebagai wakil pialang berjangka. Ketentuan ini dapat kita lihat pada Pasal 2 Peraturan Kepala Bappebti No. 64/Bappebti/Per/1/2009 tentang Ketentuan Teknis Perilaku Pialang Berjangka. Pasal 2 peraturan Kepala Bappebti tersebut menyatakan:

1. Hanya wakil pialang berjangka yang berwenang berhubungan langsung dengan calon nasabah atau nasabah dalam rangka pelaksanaan transaksi kontrak berjangka;

2. Berhubungan langsung sebagaimana dimaksud pada ayat (1) adalah melakukan hubungan dengan calon nasabah atau nasabah secara tatap muka langsung ataupun melalui sarana elektronik tanpa melalui pihak lain;

3. Ruang lingkup kewenangan wakil pialang berjangka dalam berhubungan langsung dengan calon nasabah sebagaimana dimaksud ayat

meliputi:

a. Menjelaskan dan menawarkan kontrak berjangka yang akan ditransaksikan;

b. Menjelaskan mengenai risiko perdagangan berjangka;

c. Menandatangani dokumen pernyataan adanya risiko;

d. Menjelaskan peraturan perdagangan (trading rules) termasuk mekanisme transaksi;

e. Menjelaskan isi dokumen perjanjian pemberian amanat; dan

f. Menandatangani dokumen perjanjian pemberian amanat.

4. pelaksanaan kewenangan sebagaimana dimaksud pada ayat (3) huruf a sampai huruf $\mathrm{f}$ terhadap seorang calon nasabah hanya dapat dilakukan oleh wakil pialang yang sama;

5. Dalam hal wakil pialang berjangka, sebagaimana dimaksud pada ayat (4) berhalangan dengan alasan yang dapat dipertanggungjawabkan sehingga tidak dapat melaksanakan kewenangannya, maka wakil pialang berjangka yang bersangkutan dapat digantikan oleh wakil pialang berjangka lain.

Dari penelitian yang dilakukan, terlihat bahwa edukasi tidak secara langsung diberikan oleh wakil pialang berjangka, melainkan oleh sales marketing perusahaan. wakil pialang lebih mengupayakan terpenuhinya formalitas pemberian edukasi tanpa diikuti oleh upaya memberikan pemahaman yang 
benar kepada setiap calon nasabah. Hal tersebut diketahui setelah dilakukan wawancara dengan responden. Dari tiga orang responden yang diwawancarai diketahui tidak satupun dari responden yang memahami tentang tatacara perdagangan berjangka, baik itu terkait dengan teknik analisa pasar, manajemen risiko dan aspek hukum perdagangan emas berjangka. Seorang responden menyatakan kalau dia telah memberikan pengakuan yang sebenarnya kepada wakil pialang berjangka bahwa dia sama sekali belum mengerti dengan apa yang telah diterangkan oleh sales marketing perusahaan, namun wakil pialang tetap melanjutkan proses perekrutan, tanpa melakukan edukasi lebih lanjut.

Ketiga, adanya pelanggaran batas kewenangan yang dilakukan oleh wakil pialang berjangka. Ada beberapa bentuk pelanggaran batas kewenangan yang dilakukan oleh sales marketing perusahaan. Salah satu bentuk pelanggaran tersebut adalah memberikan garansi keuntungan kepada nasabah. Larangan mengajak calon nasabah dengan memberikan iming-iming keuntungan diatur dalam Pasal 57 angka 2 UndangUndang Nomor 10 Tahun 2011 tentang Perdagangan Berjangka Komoditi. Ketentuan tersebut berbunyi, "setiap pihak dilarang secara langsung atau tidak langsung mempengaruhi pihak lain untuk melakukan transaksi kontrak berjangka, kontrak derivatif syariah, dan/atau kontrak derivatif lainnya dengan cara membujuk atau memberi harapan keuntungan yang di luar kewajaran". Ketentuan pelarangan untuk melakukan transaksi dengan pemberian iming-iming tersebut dipertegas lagi dengan dikeluarkannya Peraturan Kepala Badan Pengawas Perdagangan Berjangka Komoditi Nomor 64/Bappebti/Per/1/2009 tentang Ketentuan Teknis Perilaku Pialang Berjangka. Dalam Pasal 7 huruf b peraturan kepala Bappebti tersebut dinyatakan, "Pegawai pialang berjangka atau pihak lainnya yang memiliki kepentingan dengan perusahaan pialang berjangka dilarang secara langsung atau tidak langsung mempengaruhi calon nasabah atau nasabah dengan memberikan informasi yang menyesatkan untuk melakukan transaksi kontrak berjangka antara lain; menawarkan pendapatan tetap (fixed income), atau bagi hasil (profit sharing)".

Untuk lebih meningkatkan efektifitas penerapan aturan, pemerintah juga telah menetapkan sanksi bagi para pihak yang melanggarnya. Sanksi tersebut diatur dalam Pasal 73E ayat (2) Undang-Undang Nomor 10 Tahun 2011 tentang Perdagangan Berjangka. Pasal tersebut menyatakan, "Setiap pihak yang menyalurkan amanat untuk melakukan transaksi kontrak berjangka, kontrak derivatif syariah, dan/atau kontrak derivatif lainnya dari pihak ketiga yang dilakukan tidak sesuai dengan ketentuan undang-undang ini dan/atau peraturan pelaksanaannya sebagaimana dimaksud Pasal 49 ayat (2), dipidana dengan pidana penjara paling singkat 1 (satu) tahun dan paling lama 4 (empat) tahun, dan denda paling sedikit Rp. 1.000.000.000,- (satu miliar Rupiah) dan paling banyak Rp. 4.000.000.000,- (empat miliar Rupiah)". 
Aswandi: Upaya Hukum Dalam Penyelesaian Sengketa Perdagangan Emas Berjangka...

Berdasarkan data yang didapatkan dari responden, pihak perusahaan, dalam hal ini sales marketing perusahaan, telah mengiming-imingi mereka dengan keuntungan yang sangat besar pada waktu perekrutan. Dengan melakukan investasi sebesar Rp. 100.000.000,- (seratus juta rupiah) sales marketing tersebut mampu menjanjikan keuntungan sebesar Rp. 1000.000,- (satu juta Rupiah) untuk setiap harinya atau berkisar antara $1 \%$ sampai dengan $2 \%$ untuk setiap harinya.

Di samping pelanggaran dalam bentuk pemberian iming-iming keuntungan, pelanggaran lain yang dilakukan oleh sales marketing perusahaan adalah memegang dan memainkan nomor akun atas nama dan untuk kepentingan nasabah. Larangan untuk memegang kode akses transaksi dan menggunakan akun nasabah secara tegas sudah diatur dalam Undang-Undang Nomor 10 Tahun 2011 tentang Perdagangan Berjangka Komoditi. Ketentuan tersebut dapat kita lihat pada Pasal 52 ayat (1) undang-undang tersebut yang menyatakan, "Pialang berjangka dilarang melakukan transaksi kontrak berjangka, kontrak derivatif syariah dan/atau kontrak derivatif lainnya untuk rekening nasabah, kecuali telah menerima perintah untuk setiap kali transaksi dari nasabah atau kuasanya yang ditunjuk secara tertulis untuk mewakili kepentingan nasabah yang bersangkutan".

Pasal 52 ayat (1) tersebut menerangkan, wakil pialang berjangka dilarang dan hanya diperbolehkan melakukan transaksi kontrak berjangka untuk rekening nasabah apabila telah menerima perintah dari nasabah atau kuasa nasabah yang ditunjuk secara tertulis untuk mewakili kepentingan nasabah untuk setiap kali transaksi. Tanpa adanya perintah dari nasabah untuk setiap kali transaksi, pialang berjangka dilarang untuk melakukan transaksi.

Pelanggaran terhadap ketentuan Pasal 52 ayat (1) tersebut akan dikenakan sanksi, sebagaimana yang telah diatur dalam pasal Pasal 73D ayat (4) UndangUndang Nomor 10 Tahun 2011 tentang Perdagangan Berjangka Komoditi. Dalam pasal tersebut dinyatakan, "Setiap pihak yang melakukan transaksi kontrak berjangka, kontrak derivatif syariah, dan/atau kontrak derivatif lainnya untuk rekening nasabah tanpa menerima perintah untuk setiap kali transaksi dari nasabah atau kuasanya yang ditunjuk secara tertulis untuk mewakili kepentingan nasabah yang bersangkutan sebagaimana dimaksud dalam pasal 52 ayat (1), dipidana dengan pidana paling singkat 1 (satu) tahun dan paling lama (3) tahun dan/atau denda paling sedikit Rp. 500.000.000,00 (lima ratus juta rupiah) dan paling banyak $\mathrm{Rp}$. 1.500.000.000,00 (satu miliar lima ratus juta rupiah)".

Penyelesaian sengketa perdagangan berjangka komoditi, khususnya pada PT. Rifan Financindo Berjangka Pekanbaru berpedoman kepada pilihan hukum yang telah disepakati para pihak, yang telah dinyatakan dalam perjanjian pemberian amanat. Namun, sebelum melakukan penyelesaian sengketa secara litigasi maupun nonlitigasi para pihak yang bersengketa diharuskan untuk 
mengupayakan penyelesaian sengketa melalui musyawarah. Keharusan untuk melakukan musyawarah tersebut dapat kita lihat pada lembar ke-lima, ketentuan Nomor 22 Perjanjian Pemberian Amanat Secara elektronik on-line antara nasabah dengan PT. Rifan Financindo Berjangka, yang menyatakan:

1. Semua perselisihan dan perbedaan pendapat yang timbul dalam pelaksanaan perjanjian ini wajib diselesaikan terlebih dahulu secara musyawarah untuk mencapai mufakat antara para pihak

2. Apabila perselisihan dan perbedaan pendapat yang timbul tidak dapat diselesaikan secara musyawarah untuk mencapai mufakat, para pihak wajib memanfaatkan sarana penyelesaian perselisihan yang tersedia di bursa berjangka

3. Apabila perselisihan dan perbedaan pendapat yang timbul tidak dapat diselesaikan melalui cara sebagaimana dimaksud pada angka (1) dan angka (2) maka para pihak sepakat untuk menyelesaikan perselisihan melalui:

a. Badan Arbitrase Perdagangan Berjangka Komoditi (BAKTI) berdasarkan peraturan dan prosedur Badan Arbitrase Perdagangan Berjangka Komoditi (BAKTI), atau

b. Pengadilan Negeri Jakarta Selatan.

Berdasarkan ketentuan tersebut di atas tata cara penyelesaian sengketa perdagangan berjangka komoditi antara nasabah dengan PT. Rifan Financindo
Berjangka dapat dilakukan dengan caracara sebagai berikut:

1. Penyelesaian Sengketa Melalui
Musyawarah Untuk Mufakat

Sebelum melakukan upaya penyelesaian sengketa perdagangan berjangka secara litigasi maupun nonlitigasi, para pihak yang bersengketa diharuskan untuk melakukan upaya penyelesaian sengketa melalui musyawarah. Ketentuan tersebut dapat juga kita lihat pada Pasal 61 huruf a Undang-Undang No 10 tahun 2011 tentang Perdagangan Berjangka Komoditi yang menyatakan, "Tanpa mengurangi hak para pihak untuk menyelesaikan perselisihan perdata yang berkaitan dengan perdagangan berjangka di pengadilan atau melalui arbitrase, setiap perselisihan wajib diupayakan terlebih dahulu penyelesaiannya melalui musyawarah untuk mencapai mufakat di antara para pihak yang berselisih".

Musyawarah dalam sengketa perdagangan berjangka, biasanya dilakukan antara nasabah dengan sales marketing perusahaan dengan didampingi oleh wakil pialang. Menurut Pasal 2 Peraturan Kepala Pengawas Perdagangan Berjangka Komoditi Nomor 125/Bappebti/Per/11/2015 tentang Pedoman Penanganan Pengaduan Nasabah, penanganan pengaduan harus dilakukan secara tepat, cepat, tertib dan dapat dipertanggungjawabkan kepada nasabah, serta terciptanya rasa keadilan bagi nasabah dan pialang berjangka sesuai dengan peraturan perundang-undangan di bidang perdagangan berjangka. 
Aswandi: Upaya Hukum Dalam Penyelesaian Sengketa Perdagangan Emas Berjangka...

Apabila penyelesaian sengketa secara musyawarah tidak membuahkan hasil, nasabah baru diperbolehkan melakukan pengaduan resmi ke perusahaan pialang berjangka. Setiap nasabah berhak untuk mendapatkan layanan atas pengaduan yang dilakukannya. Setiap pengaduan harus dilakukan sesuai dengan tata cara yang telah diatur dalam peraturan kepala Bappebti. Walaupun tidak diminta oleh nasabah, peraturan mewajibkan pialang berjangka untuk memberikan penjelasan mengenai Prosedur Operasional Strandar (POS) tentang penanganan pengaduan kepada nasabah atau kuasanya yang mengajukan pengaduan. Ketentuan tersebut dapat kita lihat dalam Pasal 8 angka (4) Peraturan Kepala Pengawas Perdagangan Berjangka Komoditi Nomor 125/Bappebti/Per/11/2015 tentang Pedoman Penanganan Pengaduan Nasabah yang menyatakan, "Pialang berjangka wajib memberikan penjelasan kepada nasabah mengenai Prosedur Operasioal Standar (POS) penanganan pengaduan pada saat nasabah atau kuasanya mengajukan pengaduan".

2. Penyelesaian Sengketa Melalui Badan Arbitrase Perdagangan Berjangka Komoditi (BAKTI)

Pengertian Arbitrase menurut Pasal 1 ayat (1) Undang-Undang Nomor 30 tahun 1999 tentang Arbitrase dan Alternatif Penyelesaian Sengketa adalah cara penyelesaian suatu sengketa perdata di luar pengadilan umum yang berdasarkan kepada perjanjian arbitrase yang dibuat secara tertulis oleh pihak yang bersengketa. Dengan demikian, sebuah sengketa perdata, baru bisa diselesaikan melalui lembaga arbitrase apabila ada perjanjian tertulis yang dibuat secara khusus maupun karena adanya klausula arbitrase yang dibuat bersamaan dan melekat pada perjanjian pokok.

Menurut Yahya Harahap, dari berbagai sumber undang-undang, peraturan dan konvensi internasional, pada dasarnya, arbitrase memiliki 2 (dua) bentuk klausula perjanjian, yaitu:

a. Pactum de compremittendo, para pihak mencantumkan badan arbitrase yang disepakati untuk menyelesaikan sengketa sebelum sengketa terjadi. Kesepakatan mengenai badan arbitrase terebut dapat dibuat dalam satu kesatuan dengan kontrak pokok, dalam suatu bentuk klausula arbitrase, namun bisa juga dibuat secara khusus, terpisah dengan perjanjian pokok. Intinya, pada Pactum de compremittendo kesepakatan arbitrase telah dibuat sebelum sengketa terjadi.

b. Acta Compromis, adalah kontrak arbitrase yang dibuat setelah timbulnya perselisihan antara dua belah pihak atau beberapa pihak (M. Yahya Harahap, 1991: 100).

Jika dikaitkan dengan dua bentuk klausula arbitrase sebagaimana yang disebutkan di atas, klausula arbitrase yang telah disepakati antara nasabah dengan PT. Rifan Financindo Berjangka Pekanbaru, tergolong kepada Pactum de compremittendo. Hal itu dapat kita lihat dari sudah adanya klausula penyelesaian sengketa sebelum terjadinya sengketa. 
Klausula arbitrase tersebut terdapat pada

Perjanjian Pemberian Amanat Secara Elektronik On-line Untuk Transaksi Kontrak Derivatif Dalam Sistem Perdagangan Alternatif.

Prosedur penyelesaian perselisihan melalui lembaga arbitrase BAKTI adalah sebagai berikut:

a. Salah satu pihak (pemohon) mendaftarkan permohonan arbitrase beserta tuntutannya kepada BAKTI. Permohonan arbitrase didaftarkan pada Sekretariat BAKTI, u.p. Ketua. Permohonan harus memuat sekurangkurangnya; nama dan alamat para pihak, penjelasan mengenai persengketaan (Posita), dan rincian tuntutan (Petitum), disertai lampiranlampiran yang diperlukan.

b. BAKTI akan meneruskan tuntutan tersebut kepada pihak yang dituntut (termohon), dan meminta termohon agar segera memberikan Jawaban terhadap tuntutan Permohonan dalam waktu 14 hari.

c. Pemohon mengusulkan satu calon arbiter, dan termohon mengusulkan pula satu calon arbiter. Kemudian kedua arbiter bersama-sama menunjuk arbiter ketiga sebagai ketua majelis arbitrase. Para pihak bisa pula menyepakati satu arbiter (arbiter tunggal). Arbiter yang dipilih adalah orang perseorangan yang tercatat dalam daftar arbiter BAKTI.

d. Majelis arbitrase/arbiter tunggal menyelenggarakan sidang pertama. Tuntutan akan dinyatakan gugur jika pemohon tidak menghadiri sidang pertama. Sedangkan jika termohon tidak hadir, akan dilakukan pemanggilan sekali panggilan. Jika termohon tidak hadir kembali pemeriksaan dapat diajukan dan diputuskan walau tanpa kehadiran termohon.

e. Pada sidang pertama, majelis arbitrase/arbiter tunggal akan mengupayakan perdamaian antara para pihak. Jika upaya perdamaian berhasil, majelis arbitrase/arbiter tunggal akan membuatkan akta perdamaian. Namun jika upaya perdamaian gagal, maka proses arbitrase dilanjutkan.

f. Arbitrase dilakukan secara tertutup dan menurut peraturan \& acara arbitrase BAKTI. Proses pemeriksaan yang meliputi pemeriksaan atas keterangan para pihak, saksi/saksi ahli, dan bukti-bukti selesai dalam waktu paling lama 180 hari sejak majelis arbitrase/arbiter tunggal terpilih. Batas waktu tersebut dapat diperpanjang jika dipandang perlu oleh majelis arbitrase/arbiter tunggal dan disepakati para pihak.

g. Dalam waktu 30 hari setelah pemeriksaan selesai (ditandai dengan penyerahan kesimpulan dari masingmasing pihak) majelis arbitrase/arbiter tunggal membacakan putusan untuk segera dilaksanakan oleh Para Pihak.

h. BAKTI akan mendaftarkan putusan tersebut pada pengadilan negeri di mana termohon berdomisili (website BAKTI, http;//bakti-arb.org).

Mekanisme mediasi dan arbitrase dapat mengurangi risiko yang biasanya 
Aswandi: Upaya Hukum Dalam Penyelesaian Sengketa Perdagangan Emas Berjangka...

muncul dalam proses beracara di pengadilan. Risiko tersebut seperti risiko waktu, reputasi bisnis dan biaya yang cukup besar. Pada umumnya penyelesaian sengketa melalui mediasi dan arbitrase lebih cepat selesai dari pada beracara di pengadilan. Tahapan untuk mencapai keputusan akhir yang mengikat para pihak dapat diukur dan diprediksi sehingga segala akibatnya terhadap kegiatan ekonomi bisa diantisipasi.

3. Penyelesaian Perselisihan Melalui Pengadilan Negeri Jakarta Selatan

Berbeda dengan penyelesaian sengketa melalui lembaga arbitrase, penyelesaian sengketa melalui peradilan tergolong kepada penyelesaian sengketa yang bersifat litigasi. Dengan demikian, dalam proses beracara, para pihak yang bersengketa terikat dengan setiap ketentuan yang lazim berlaku di lembaga peradilan dan berkewajiban untuk melaksanakan setiap putusan yang telah ditetapkan.

Dalam perjanjian pemberian amanat secara elektronik on-line untuk transaksi kontrak derivatif dalam sistem perdagangan alternatif yang berlaku di PT. Rifan Financindo Berjangka, satu-satunya opsi yang ditawarkan perusahaan terkait lembaga peradilan yang berwenang menyelesaikan sengketa dalam perdagangan berjangka komoditi adalah Pengadilan Negeri Jakarta Selatan. Kontrak baku yang telah disepakati tidak memberikan peluang kepada nasabah untuk dapat mengajukan gugatan ke lembaga peradilan selain yang telah disepakati dalam kontrak, yaitu Pengadilan
Negeri Jakarta Selatan. Keberadaan klausula ini telah menghapuskan hak-hak nasabah untuk mengajukan gugatan ke Pengadilan Negeri di tempat dimana nasabah berdomisili dan di tempat kedudukan kantor cabang PT. Rifan Financindo Berjangka yang tersebar di beberapa daerah di Indonesia. Hal tersebut tentunya sangat memberatkan bagi nasabah.

Penyelesaian sengketa atau perkara keperdataan di pengadilan, termasuk sengketa perdagangan emas berjangka harus tetap mengacu pada asas-asas hukum sebagaimana yang diatur dalam UndangUndang Nomor 48 Tahun 2009 tentang Kekuasaan Kehakiman. Salah satu asas yang harus diperhatikan dalam penyelesaian sengketa adalah asas penyelesaian perkara secara sederhana, cepat dan biaya ringan. Pasal 4 ayat (2) Undang-Undang Nomor 48 Tahun 2009 tentang Kekuasaan Kehakiman tersebut menyatakan, Pengadilan membantu pencari keadilan dan berusaha mengatasi segala hambatan dan rintangan untuk dapat tercapainya peradilan yang sederhana, cepat, dan biaya ringan. Sederhana artinya pemeriksaan dan penyelesaian perkara dilakukan secara efisien dan efektif. Biaya ringan dimaksudkan bahwa berperkara harus dilakukan dengan biaya yang tidak memberatkan dan dapat dipikul oleh pencari keadilan. Namun demikian, dalam pemeriksaan dan penyelesaian perkara harus tetap dilakukan dengan tidak mengabaikan ketelitian dalam mencari kebenaran dan keadilan (Muhammad Syaifuddin, 2012: 393). 
Dari hasil penelitian yang telah dilakukan, ada beberapa kendala yang ditemukan dalam upaya penyelesaian sengketa perdagangan berjangka komoditi di PT. Rifan Financindo Berjangka Pekanbaru. Kendala-kendala tersebut adalah :

1. Pilihan Forum Penyelesaian Sengketa Yang Memberatkan Nasabah

Tolok ukur keabsahan sebuah kontrak dalam sistem hukum perjanjian di Indonesia adalah syarat sahnya perjanjian sebagaimana yang terdapat dalam pasal 1320 KUH Perdata, yang menyatakan untuk syahnya sebuah perjanjian diperlukan empat syarat:

a. Sepakat mereka yang mengikatkan diri;

b. Kecakapan untuk membuat perikatan;

c. Suatu hal tertentu; dan

d. Suatu sebab yang halal.

Sebuah kontrak, idealnya, akan selalu dapat mengakomodir keinginan para pihak yang membuatnya. Untuk itu, negosiasi dan tawar menawar adalah sebuah kelaziman dalam proses pembuatan kontrak. Akan tetapi, dalam prakteknya, tidak jarang kontrak yang telah disepakati ditetapkan secara sepihak oleh salah satu pihak yang membuat kontrak. Tidak jarang kontrak tersebut tidak sepenuhnya sesuai dengan keinginan para pihak yang membuatnya.

Terkait dengan upaya penyelesaian sengketa antara nasabah dengan PT. Rifan Financindo, nasabah dihadapkan pada ketentuan harus menyetujui klausula penyelesaian sengketa yang telah ditetapkan oleh perusahaan pada perjanjian pemberian amanat, sebagaimana yang telah diterangkan sebelumnya. Ketentuan yang terdapat dalam perjanjian pemberian amanat tersebut tidak hanya dinilai memberatkan nasabah, akan tetapi lebih jauh lagi telah menyebabkan hilangnya hak-hak nasabah untuk mendapatkan peradilan yang berkeadilan, murah dan sederhana. Opsi pertama yang ditetapkan oleh perusahaan, jika upaya musyawarah untuk mufakat tidak membuahkan hasil, adalah penyelesaian sengketa melalui Badan Arbitrase Perdagangan Berjangka Komoditi. Badan arbitrase ini hanya memiliki kantor, satu-satunya, di Jakarta. Itu berarti untuk dapat menyelesaikan sengketa melalui BAKTI, nasabah PT. Rifan yang ada di Pekanbaru harus menyediakan tambahan waktu dan dana yang tentunya tidak sedikit.

Di samping karena keberadaan BAKTI yang relatif jauh dari domisili nasabah PT. Rifan Financindo Berjangka Pekanbaru, banyak pihak yang meragukan netralitas BAKTI dalam menjalankan tugasnya. Keraguan tersebut tentunya bukan tanpa alasan, mengingat BAKTI sebagai peradilan swasta yang diharapkan indenpenden ini diprakarsai dan beranggotakan Asosiasi Pialang Berjangka Indonesia (APBI), dan Ikatan Perusahaan Pedagang Berjangka Indonesia (IP2BI) yang sekarang telah melebur menjadi Asosiasi Perdagangan Berjangka Komoditi Indonesia (Aspebtindo) (Website Aspetindo, http;//www.aspetindo.org)

Aspetindo berdiri berdasarkan Keputusan Kepala Badan Pengawas 
Aswandi: Upaya Hukum Dalam Penyelesaian Sengketa Perdagangan Emas Berjangka...

Perdagangan Berjangka Komoditi Nomor: 19/BAPPEBTI/SP/04/2015 Tentang Pemberian Persetujuan kepada Asosiasi Perdagangan Berjangka Komoditi Indonesia (Aspebtindo) sebagai Asosiasi Industri Perdagangan Berjangka. Menurut Sutriono Edi, Kepala Bappebti, pendirian Aspebtindo merupakan amanat dari Undang-Undang Nomor 10 Tahun 2011 tentang Perubahan atas Undang-Undang Nomor 32 Tahun 1997 tentang Perdagangan Berjangka Komoditi. Tujuan dari pendirian Aspebtindo adalah untuk memperjuangkan kepentingan para anggotanya dan pengembangan industri Perdagangan Berjangka Komoditi di Indonesia (http;//wartaekonomi.co.id)

Keadaan seperti ini tentunya rentan dengan konflik kepentingan. BAKTI yang diharapkan mampu memberikan keadilan kepada para pihak yang bersengketa, yaitu nasabah dan perusahaan pialang berjangka, didirikan dan beranggotakan assosiasi perusahaan pialang berjangka dengan tujuan untuk memperjuangkan kepentingan anggotanya. Karena itu, banyak pihak yang meragukan netralitas BAKTI dalam penyelesaian sengketa perdagangan berjangka.

Opsi kedua dalam penyelesaian sengketa perdagangan berjangka yang terdapat dalam klausula penyelesaian sengketa adalah penyelesaian sengketa secara litigasi atau melalui lembaga pengadilan (in court dispute setlement). Sebagai pressure value dan the last resort, peran peradilan masih tetap diakui. Terkait dengan penyelesaian sengketa Perdagangan berjangka pada PT. Rifan
Financindo Berjangka Pekanbaru, di samping karena kurangnya minat dan kepercayaan mayarakat untuk beracara melalui pengadilan umum, pilihan domisili hukum juga menjadi kendala bagi kebanyakan nasabah. Satu-satunya lembaga peradilan yang telah ditetapkan oleh PT. Rifan Financindo Berjangka dan telah disetujui oleh nasabah adalah Pengadilan Negeri Jakarta Selatan. Pihak perusahaan tidak memberikan kesempatan kepada nasabah untuk membuat opsi lain, seperti menjadikan Pengadilan Negeri Pekanbaru sebagai salah satu pilihan dalam upaya penyelesaian sengketa. Hal tersebut tentunya sangat memberatkan nasabah dalam berperkara, karena keberadaannya yang jauh dari domisili nasabah.

Menjadikan Pengadilan Negeri Pekanbaru sebagai salah satu opsi dalam pemilihan badan penyelesaian sengketa perdagangan berjangka komoditi antara nasabah dengan PT. Rifan Financindo Berjangka Pekanbaru merupakan suatu pilihan yang logis. Hal tersebut mengingat kedudukan perusahaan dan domisili nasabah yang sebagian besar sama-sama berada di Pekanbaru dan juga karena locus dugaan pelanggaran hukum terjadi di Pekanbaru. Tidak ada yang salah dan tidak ada yang akan dirugikan jika penyelesaian sengketa dilakukan di Pengadilan Negeri Pekanbaru. Malah opsi tersebut samasama bermanfaat bagi PT. Rifan Financindo dan juga bagi nasabahnya. Dengan demikian, penyelesaian sengketa yang berkeadilan, cepat dan biaya murah betul-betul bisa diwujudkan. 
2. Pelanggaran Prosedur Operasional Standar Penyelesaian Sengketa

Dari beberapa kali wawancara yang penulis lakukan dengan nasabah yang pernah/sedang melakukan upaya penyelesaian sengketa dengan PT. Rifan Financindo Berjangka Pekanbaru, ada beberapa ketentuan, terkait dengan penyelesaian sengketa yang belum dilaksanakan oleh Perusahaan. Keadaan tersebut membuat penyelesaian sengketa menjadi berbelit-belit, bahkan ada nasabah yang mengurungkan niatnya untuk menyelesaikan sengketa setelah mengetahui langkah-langkah yang harus dilaluinya dalam mengajukan pengaduan. Sayangnya pihak perusahaan bukannya memberikan penjelasan malah memanfaatkan ketidaktahuan nasabah tersebut. Padahal, peraturan mengharuskan perusahaan untuk menjelaskan Peraturan Operasional Standar (POS) dalam berperkara kepada nasabah.

Beberapa ketentuan yang diabaikan PT. Rifan Financindo Berjangka dalam upaya penyelesaian sengketa diantaranya adalah:

a. PT. Rifan tidak memiliki atau setidaknya tidak menjelaskan Peraturan Operasional Standar (POS) tentang penanganan pengaduan oleh nasabah.

b Tidak maksimalnya upaya mempublikasikan keberadaan unit yang berfungsi memberikan pelayanan pengaduan kepada nasabah atau calon nasabah dan tidak adanya upaya untuk memastikan bahwa nasabah dan/atau calon nasabah mengetahui keberadaan dan fungsi unit pelayanan pengaduan tersebut sebagaimana yang diatur dalam Pasal 5 ayat (2) huruf $\mathrm{f}$ Peraturan Kepala Bappebti Nomor 125/Bappebti/ Per/11/2015 yang menyatakan, "Dalam melakukan penanganan pengaduan sebagaimana dimaksud pada ayat (1) pialang berjangka wajib mempublikasikan keberadaan unit yang berfungsi untuk memberikan pelayanan pengaduan kepada nasabah dan/atau calon nasabah secara tertulis dan/atau elektronik dan memastikan nasabah dan/atau calon nasabah mengetahui keberadaan unit tersebut dan fungsinya."

c. Pialang berjangka tidak menyampaikan bukti penerimaan pengaduan kepada nasabah atau kuasanya pada saat pengaduan diajukan. Memberikan bukti penerimaan pengaduan kepada nasabah atau kuasa nasabah merupakan kewajiban dari perusahaan, seperti yang diamanatkan Pasal Pasal 9 ayat (1) Peraturan Kepala Bappebti Nomor 125/Bappebti/Per/11/2015, yang berbunyi, "Pialang berjangka wajib menyampaikan bukti penerimaan pengaduan kepada nasabah atau kuasanya pada saat pengaduan diajukan dan dokumen pendukung dinyatakan lengkap". Bukti Pengaduan tersebut akan dijadikan pegangan dan persyaratan untuk dapat melanjutkan penyelesaian sengketa ke tahap berikutnya, yaitu melalui perusahaan bursa berjangka. 
Aswandi: Upaya Hukum Dalam Penyelesaian Sengketa Perdagangan Emas Berjangka...

3. Pemahaman Nasabah Terhadap Proses

Dan Aspek Hukum Penyelesaian Sengketa

Terkait dengan nasabah, kendala dalam upaya penyelesaian sengketa perdagangan berjangka komoditi lebih disebabkan karena kurangnya pengetahuan nasabah tentang hak-hak nasabah dan Prosedur Operasional Standar dalam melakukan pengaduan. Bahkan ada nasabah yang sama sekali belum membaca kontrak secara lengkap. Ketika terjadi sengketa, nasabah tersebut tidak tahu apa yang harus dilakukan. Keadaan tersebut dibenarkan oleh Veri Aggrijono, Kepala Bagian Pelanggaran Transaksi BAPPEBTI, yang menyatakan Hambatan yang dihadapi penyelesaian sengketa perdagangan berjangka komoditi diantaranya adalah banyak masyarakat di daerah yang tidak tahu ketika ada pelanggaran harus mengadu kepada siapa (Martina Ratna Paramitha Sari, 2013: 11).

Dengan disepakatinya perjanjian pemberian amanat, berarti nasabah dan pialang berjangka telah sepakat untuk menunjuk Badan Arbitrase Perdagangan Berjangka Komoditi atau Pengadilan Negeri Jakarta Selatan sebagai pilihan forum dalam penyelesaian sengketa. Hal ini sekaligus meniadakan hak para pihak untuk mengajukan sengketa kepada pengadilan dan badan arbitrase lain. Pada sisi lain, klausula arbitrase yang disepakati tersebut juga menyebabkan pengadilan dan lembaga arbitrase lain tidak berwenang untuk mengadili sengketa para pihak yang telah terikat dengan perjanjian pemberian amanat secara elektronik on-line, yang di dalamnya juga telah mencantumkan klausula penyelesaian sengketa. Ketentuan tersebut dapat kita lihat pada Pasal 3 Undang-Undang Nomor 30 Tahun 1999 tentang Arbitrase dan Alternatif Penyelesaian Sengketa, yang berbunyi, "Pengadilan Negeri tidak berwenang untuk mengadili sengketa para pihak yang telah terikat dalam perjanjian arbitrase".

Ketentuan yang terdapat pada Pasal 3 tersebut diperkuat lagi dengan Pasal 11 Undang-Undang Nomor 30 Tahun 1999 yang menyatakan:

(1) Adanya suatu perjanjian arbitrase tertulis meniadakan hak para pihak untuk mengajukan penyelesaian sengketa atau beda pendapat yang termuat dalam perjanjian ke Pengadilan Negeri.

(2) Pengadilan Negeri wajib menolak dan tidak ikut campur tangan dalam suatu penyelesaian sengketa yang telah ditetapkan melalui arbitrase, kecuali dalam hal-hal tertentu yang ditetapkan dalam undang-undang ini.

Kurangnya pengetahuan nasabah terhadap aspek hukum dan Prosedur Operasional Standar penyelesaian sengketa mengakibatkan tidak optimalnya upaya hukum yang bisa dilakukan. Nasabah tidak mempunyai daya tawar yang kuat sehingga kendali penyelesaian sengketa sepenuhnya berada pada perusahaan. Nasabah tidak tahu apa saja yang menjadi haknya dan apa batas kewenangan wakil pialang dalam penyelesaian sengketa. Ketika upaya musyawarah dengan sales marketing dan wakil pialang berjangka tidak menghasilkan kata sepakat, nasabah seharusnya melanjutkan upaya penyelesaian sengketa dengan melakukan 
pengaduan secara resmi kepada direktur kepatuhan. Direktur kepatuhan berkewajiban untuk menerima dan menjelaskan Prosedur Operasioanl Standar pengaduan kepada nasabah. Dalam Prosedur Operasional tersebut telah diatur tentang tatacara dan batas waktu yang diperlukan dalam setiap proses tahapan penanganan pengaduan. Akan tetapi, karena ketidaktahuannya, nasabah beranggapan dengan tidak adanya kata sepakat dalam musyawarah merupakan akhir dari upaya penyelesaian sengketa. Akibatnya nasabah tidak mendapatkan solusi yang tepat terkait dengan pengaduan yang dilakukannya.

\section{SIMPULAN}

Ada tiga penyebab terjadinya sengketa perdagangan berjangka komoditi pada PT. Rifan Financindo Berjangka Pekanbaru. Pertama, ketidakpahaman nasabah terhadap tata cara perdagangan berjangka. Kedua, Ketidakpahaman nasabah terhadap aspek hukum perdagangan berjangka komoditi. Ketiga, pelanggaran terhadap batas-batas kewenangan yang dilakukan oleh sales marketing perusahaan dan wakil pialang berjangka. Untuk menyelesaikan sengketa tersebut, ada tiga upaya hukum yang dapat dilakukan, yaitu ; penyelesaian sengketa melalui musyawarah untuk mufakat, penyelesaian sengketa melalui Badan Arbitrase Perdagangan Berjangka Komoditi (BAKTI) dan penyelesaian sengketa melalui Pengadilan Negeri Jakarta Selatan. Kendala-kendala yang ditemui dalam penyelesaian sengketa tersebut adalah : Pertama, pilihan forum penyelesaian sengketa yang memberatkan nasabah. Kedua, pelanggaran Prosedur
Operasional Standar (POS) penyelesaian sengketa. Ketiga, kurangnya pemahaman nasabah terhadap proses dan aspek hukum dalam penyelesaian sengketa perdagangan berjangka.

\section{UCAPAN TERIMA KASIH}

Selesainya penelitian ini tentunya tidak terlepas dari dukungan serta bantuan dari berbagai pihak. Oleh karena itu, penulis mengucapkan terima kasih yang sebesar-besarnya kepada Dr. Hj. Yulfasni, S.H., M.H. dan Bapak H. Syahrial Razak, S.H., M.H. yang telah memberikan bimbingan dan masukan kepada penulis dalam melakukan penelitian ini. Kepada Bapak Prof. Dr. Tafdil Husni, S.E., M.B.A. selaku Rektor Universitas Andalas Padang dan Bapak Dr. Busyra Azheri, S.H., M.H. selaku Dekan Fakultas Hukum Universitas Andalas Padang yang telah memberikan kesempatan kepada penulis untuk menimba ilmu dan melakukan penelitian.

\section{DAFTAR PUSTAKA}

\section{Buku-buku:}

Agus Yudha Hernoko, 2014, Hukum Perjanjian - Asas Proporsionalitas dalam Kontrak Komersial, Cetakan ke 4, Kencana Prenada Media Grop, Jakarta.

Ellen May, 2011, Smart Traders Not Gamblers, Cetakan ke-empat, Kompas Gramedia, Jakarta

Ishaq, 2017, Metode Penelitian Hukum, Alfabeta, Bandung.

Martina Ratna Paramitha Sari, 2013, Pengawasan BAPPEBTI (Badan Pengawas Perdagangan Berjangka Komoditi) Terhadap Pialang 
Aswandi: Upaya Hukum Dalam Penyelesaian Sengketa Perdagangan Emas Berjangka...

Perdagangan Berjangka Dalam Hal Tindakan Penyalahgunaan Dana Nasabah, Universitas Brawijaya, Malang. (Jurnal Ilmiah)

Muhammad Syaifuddin, 2012, Hukum Kontrak - Memahami Kontrak Dalam Perspektif Filsafat, Teori, Dogmatik, dan Praktisi Hukum, Mandar Maju, Bandung.

M.Yahya Harahap, 1991, Arbitrase, Pustaka Kartini, Jakarta

Peter Mahmud Marzuki, 2016, Penelitian Hukum (edisi Revisi), Cetakan ke 12, Prenadamedia Group, Jakarta

Philipus M. Hadjon, 1987, Perlindungan Hukum Bagi Rakyat Indonesia, PT. Bina Ilmu, Surabaya

Putu Subada Kusuma, 2007, Menghindari Kontrak Bermasalah dan Upaya Penyelesaian Kontrak Bermasalah, BPKH Fakultas Hukum Universitas Atmajaya, Jakarta.

Rachmadi Usman, 2013, Pilihan Penyelesaian Sengketa di Luar Pengadilan, Cetakan ke 2, PT. Citra Aditya Bakti, Bandung.

Salim H.S. dan Erlis Septiana Nurbani, Penerapan Teori Hukum Dalam Penelitian Tesis dan Disertasi, RajaGrafindo Persada, Jakarta

Satjipto Raharjo, 2000, Ilmu Hukum, PT. Citra Aditya Bakti, Bandung.

Sorjono Soekanto dan Sri Mamadji, 2014, Penelitian Hukum Normatif, Cetakan ke 16, PT. Raja Grafindo Persada, Jakarta.

Suyud Margono, 2010, Penyelesian Sengketa Bisnis-Alternative Disputes Resolutions (ADR), Ghalia Indonesia, Bogor

\section{Peraturan Perundang-undangan:}

Undang-Undang Nomor 10 Tahun 2011 tentang Perubahan Undang-Undang Nomor 32 tahun 1999 tentang Perdagangan Berjangka Komoditi

Undang-Undang Nomor 30 Tahun 1999 tentang Arbitrase dan Penyelesaian Sengketa

Undang-Undang Nomor 48 Tahun 2009 tentang Kekuasaan Kehakiman.

Peraturan Kepala Badan Pengawas Perdagangan Berjangka Komoditi Nomor 64/BAPPEBTI/PER/1/2009 tentang Perubahan atas Peraturan Kepala BAPPEBTI Nomor 63/BAPPEBTI/Per/9/2008 tentang Ketentuang Teknis Kelakuan Pialang Berjangka.

Peraturan Kepala Badan Pengawas Perdagangan Berjangka Komoditi Nomor 107/BAPPEBTI/PER/11/2013 tentang Penerimaan Nasabah Secara Elektronik On-line di Bidang Perdagangan.

\section{Websites:}

Aspebtindo, http;//www.aspepbtindo.org

BAKTI, http;//www.bakti-arb.org

BAPPEBTI, http;//www.bappebti.go.id http;//www.wartaekonomi.co.id

PT. Rifan Financindo Berjangka Pekanbaru, $\quad$ http;//www.rfberjangka.com 